

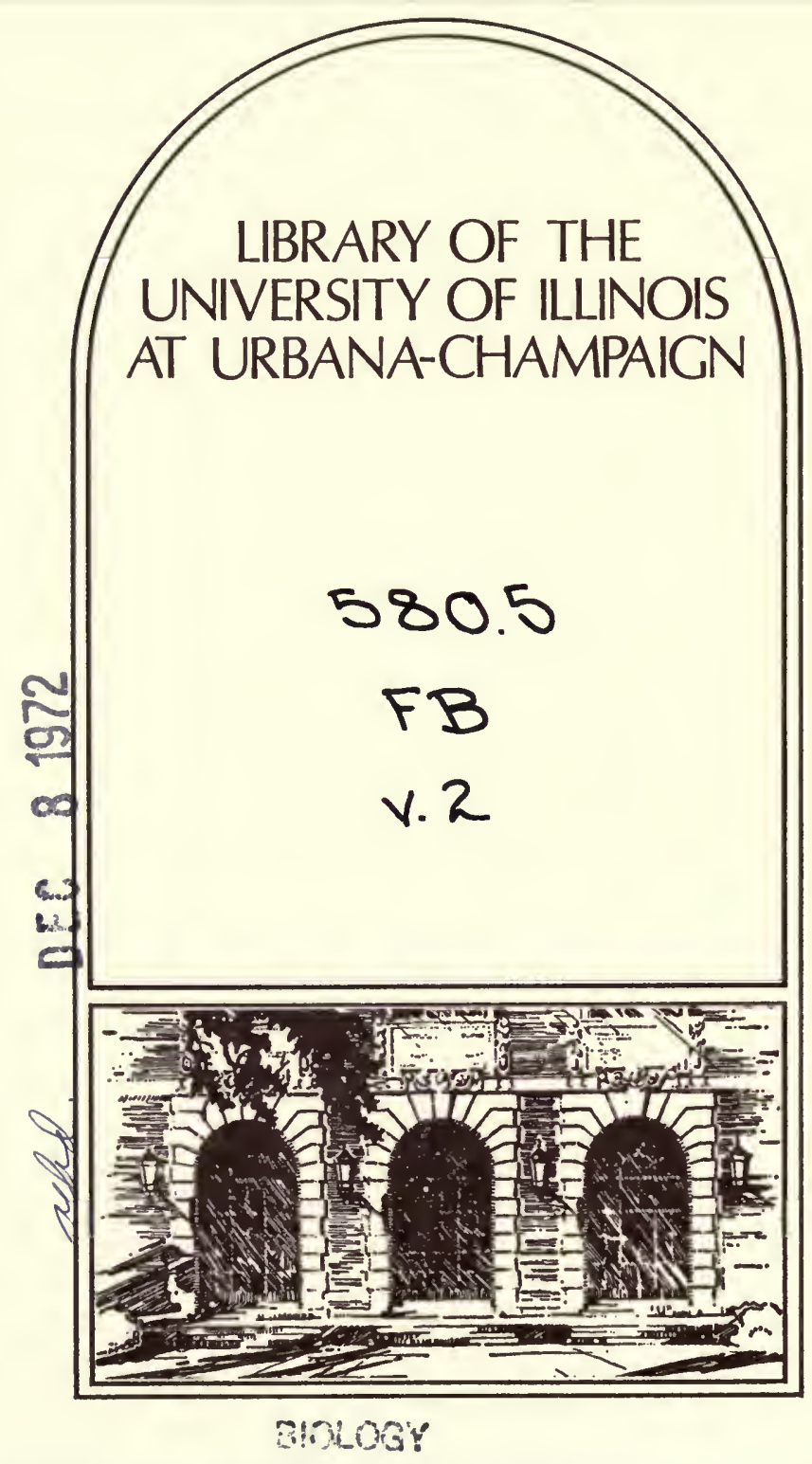






Field Museum of Natural History.

\section{Publication 172.}

Botanical Series.

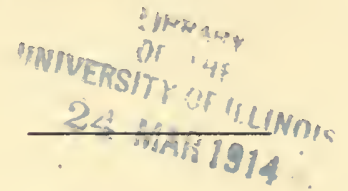

Vol. II, No. 9.

\section{THE GENERA PEDILANTHUS AND} CUBANTHUS, AND OTHER AMERICAN EUPHORBIACEAE

BY

Charles Frederick Millspaugh.

\section{TWO NEW STONECROPS FROM GUATEMALA \\ BY \\ Raymond Hamet.}

Charles Frederick Millspaugh, Curator, Department of Botany.

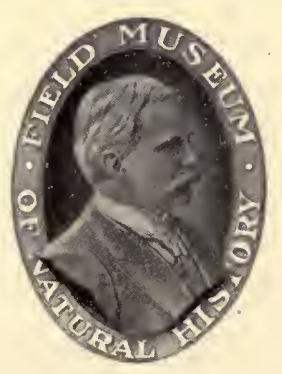

Chicago, U. S. A. December, I9I3. 




\section{KEY}

INVOLUCRE SHOE-SHAPED. Appendix smaller than the tube.

Lobe of the appendix entire:

Tube glabrous without and within:

Male and female pedicels hairy

Male pedicels hairy, female glabrous:

Appendix one third the length of the tube:

Lobe hairy-margined

Lobe not hairy-margined

Appendix one half the length of the tube

Male and female pedicels glabrous:

Leaves glabrous

Leaves pubescent:

Bracts minute, cuculliform, style 6-toothed

Bracts large, foliaceous; style 3-lobed

Tube glabrous without, hairy within

Tube pubescent without, glabrous within:

Bractlets longer than the peduncles

Bractlets half the length of the peduncles, or less:

Male and female pedicels puberulent throughout

Male and female pedicels puberulent above

Male pedicels glabrous, female pubescent at base .

Lobe of the appendix bipartite:

Colored floral bracts conspicuous: exceeding the inflorescence:

Involucral tube glabrous:

Glands of the appendix 2

Glands of the appendix 4

Involucral tube puberulent:

Capsule cornuate

Capsule not cornuate:

Male and female pedicels glabrous:

Lobes of the appendix laterally compressed:

Lobes glabrous

Lobes puberulent

Lateral and fifth lobes of the tube flabellate

Lateral and fifth lobes of the tube linear

Male pedicels glabrous, female pubescent:

Filaments and anthers glabrous

Filaments and anthers pubescent

Involucral tube hairy

Colored floral bracts not exceeding the inflorescence:

Bracts the length of the peduncles

2 tithymaloides

3 Deamii

4 jamaicensis

5 parasiticus

6 Pringlei

7 Smallii

8 padifolius

9 angustifolius

Io bahamensis

I I Fendleri

I2 Grisebachii

13 articulatus

I4 bracteatus

I5 spectabilis

Colored floral bracts wanting:

Peduncle posteriorly affixed to the tube:

Appendix projected along the margin of the fissure:

Peduncles glabrous

Peduncles puberulous

Appendix not projected along the margin of the fissure:

Tube glabrous within

Tube hairy within

Peduncle centrally affixed to the tube

- 16 Greggii

I 7 Olsson-Sefferi

I 8 involucratus

I9 rubescens

20 Palmeri

2 I tomentellus

22 Pavonis

23 macradenius

24 Erstedi

25 aphyllus

26 nodiflorus

27 cymbiferus

28 macrocarpus

Lobe of the appendix tripartite:

Two of the divisions superior, one inferior

All three divisions on one plane

INVOLUCRE HOOD-SHAPED. Appendix larger than the tube

29 peritropoides 30 Itzæus 3I Finkii 
I. Pedilanthus Retusus Benth. in Hook. Jour. and Kew Misc., 6:32 I. I 854 .

Shrubby 9 dm.-1.50 m.: leaves glabrous, ovate, $3.8-5 \mathrm{~cm}$. long, $2.5 \mathrm{~cm}$. broad, subsessile, oblique, cuneate at the base, retuse, lightly keeled beneath. Cymes terminal and upper axillary, short. Involucres 7-8 $\mathrm{mm}$. long: tube glabrous, thrice as long as the appendix; male and female pedicels hairy; appendix lobe entire, truncate, thickened (glandular sic.) slightly below the apex, 4-glandular. Capsule large, rotund; seeds subcarinate on the dorsum.

Differs from P: tithymaloides in the shape of the leaves, the hairy female pedicel, smaller involucres, and the lip of the appendix being thickened at the apex.

Type locality: Colombia, Barra, Rio Negro, Spruce I469. Type in herb. Boissier, Geneva.

Distribution: Venezuela, Margarita Island, Johnson 59.

2. Pedilanthus tithymaloides (L.) Poit. An. Mus. Paris, i9:390. I8I2.

Tithymaloides myrtifolius Curassavicus Commel. Hort., t. I6. I 706. Euphorbia tithymaloides Linn. Hort. Cliff., I98. I737: Sp. P1., 453. I 753 .

Euphorbia myrtifolia Lam. Dict., $2: 4$ I9. $\quad$ I 786.

Crepidaria myrtifolia Haw. Pl. Succ., I36. I8I 2.

Euphorbia carinata Don. Hort. Cantab., Ed. 9:195. I819.

Euphorbia canaliculata Lodd. Bot. Cab., t. 727. I822.

Pedilanthus canaliculatus Sweet, Hort. Brit., ed. I:355. I827.

Pedilanthus myrtifolius Lk. Hort. Bot. Berol., 2:I8. 1833 .

Pedilanthus carinata Raf. F1. Tell., 4:II 7. $\quad$ I836.

Pedilanthus imyrsifolius Raf. loc. cit.

Shrubby I.20-I.80 m.; leaves glabrous, subsessile, cuneate at the base, ovate or oblong, $3 \cdot 5^{-7} \cdot 5 \mathrm{~cm}$. long, apex acute often recurved, margin subundulate, the mid-vein often prominently undulate-carinate beneath. Cymes terminal, dense; floral leaves ovate, long-acuminate, slightly longer than the peduncles, early deciduous. Involucres purple, I.I-r.3 mm. long; tube thin, smooth. Appendix 4-glandular, the lobe linear, short. Male pedicels hairy, female glabrous. Style shortly bifid. Capsule $7.5 \mathrm{~mm}$. long, $9 \mathrm{~mm}$. broad, truncate at base and apex, coccæ keeled; seeds ovate, $5 \mathrm{~mm}$. long.

Type locality: CuraçAo.

Distribution: Venezuela, Lyon; Gollmer. Colombia, Holton; H. H. Smith I295. Guatemala, 2072, 6764 John Donnell-Smith; 50II 
Shannon. Honduras, 5467 Thieme. Mexico, Nickels. Сuba, de la Ossa; de la Sagra; Wright, Britton, Britton \&o Cowell I2512; Combs 498. Santo Domingo, Poiteau. Porto Rico, Sintenis 3698, 5717; Mr. Eo Mrs. Heller 34; Millspaugh I 57. FLORIDA, Britton 28I. Bahamas, Brace 4I44; Britton \& Millspaugh 579I. St. Croix, Ricksecker. Montserrat, Shafer 2i6. Barbados, Dash 63I. Grenada, Broadway.

Illustrations: Commel. Hort., t. 91 ; Jacq. Amer., t. 92 ; Descourt. Ant., t. II6. Bot. Cab., t. 727; Bot. Reg., t. 837; Bot. Mag., t. 25 I4.

\section{Pedilanthus Deamii Millsp. sp. nov.}

Shrubby; branches smooth, leafy above, naked below, young leafy branchlets tomentose. Leaves thin, sessile, ovate to suborbicular, inæquilateral, acute, narrowed to the base, crispidulous-puberulous on both surfaces, $4.5^{-6} \mathrm{~cm}$. long, $2.5-3.5 \mathrm{~cm}$. wide, midrib prominent beneath. Cymes nodal, simply bi-cephalic or cymose-bicephalic; bracts small (one fourth the length of the peduncles), cucullate, tomentose; peduncles smooth, 5-6 mm.; involucres small and slender, I. $2 \mathrm{x}$ $.3 \mathrm{~cm}$.; tube walls very thin, lower notch shallow, upper fissure extending to the appendix, few-ciliate at the posterior third, principal lobes ovate, erose-dentate, few-ciliate in the sulcus, lateral lobes ligulate, one third free; the apices slightly rounded-truncate, ciliate. Appendix small, less than one third the length of the tube, the lip ligulate, truncate, retuse; glands 4, scutelliform. Male pedicels hairy at the aipex, filaments hairy; female pedicel glabrous; style slender, slightly 3-lobed at the apex. Capsule smooth, strongly 3 -coccous; seeds grayish-olive, subcylindric, apiculate, $3.8 \times 2.5 \mathrm{~mm}$., irregularly and minutely mottled. Type locality: Guatemala, Fiscal, in ravines, alt. $3700 \mathrm{ft}$.; May 3r, I90I, Chas. C. Deam 608I. Type in herb. Field Museum of Natural History, Chicago, sheet No. 247.005. Distribution: Known only from the type.

\section{Pedilanthus jamaicensis Millsp. \&\& Britton. sp. nov.}

Shrubby, $4 \mathrm{dm}$. high; branches tenuous, glabrous. Leaves short petioled $(5 \mathrm{~mm}$.), minutely and sparsely puberulous, oblong to ovate, 3-I0 $\mathrm{cm}$. long, narrowed to the petiole, apex blunt. Cymes nodal; involucres $\mathrm{I} \mathrm{cm} . \mathrm{x}_{4} \mathrm{~mm}$; t tube-walls thin, the superior fissure open back to the appendix, inferior notch about one fourth the length of the tube; main lobes ovate, the lateral rectangular-oblong, one half free, all fimbrio-ciliate; male flowers long-exserted, filament one quarter the length of the glabrous pedicel; female pedicel glabrous; style minutely 3 -forked at the apex the lobes 2-cleft. Appendix about one half the 
length of the tube, lobe deltoid-ligulate, notched at the truncate apex, ciliate-margined; glands 4 , small, scutellate, thin.

Type locality: Jamaica, Negril vicinity, March, 1908, N. L. Britton \&o Arthur Hollick, 2067. Type in herb. New York Botanical Garden. Distribution: Jamaica, Harris .10.238.

5. Pedilanthus parasiticus'K1. \& Gke. (nec Boiss.). Tricocc., I05. i 859.

Euphorbia parasitica Pavon in herb.

Pedilanthus ramosissimus Boiss. in D. C. Prodr., I5:5. 1862.

Shrubby, stem $15.3 \mathrm{~cm}$., alternately and repeatedly short-branched; branches as thick as a goose quill. Leaves sessile, rotund or subcordate at the base, somewhat crisp-puberulent beneath, undulate, the larger $2.5 \mathrm{~cm}$. Cymes at the apex of the attenuate floral branchlets which are I. - $-8 \mathrm{~cm}$. long, $\mathrm{r} .5^{-2} \mathrm{~cm}$. diameter, capitate, densely many involucred; leaves of the inflorescence ovate-oblong, acute, deciduous; involucres small, 7-r I mm. ( $8 \times 4 \mathrm{~mm}$.) long, the tube glabrous, its main lobes broadly rounded, ciliate, the superior fissure two thirds the length of the tube; inferior notch deep; lateral lobes short; oblong, one third free at their rounded, ciliate apex; fifth lobe ligulate-spatulate, free to the base, rounded and entire at the ciliate apex; male and female pedicels glabrous. Appendix one third the length of the tube, its lip ligulatedeltoid, retuse; glands 2; large, shaped like a ruptured anther, stipitate. Type locality: Mexico, Ruiz \& Pavon. Type (visa) in herb. Boissier,

Geneva.

6. Pedilanthus Pringlei Robinson, Proc. Amer. Acad., 29:322. I894.

Shrubby, I.20-1.50 m.; stems smooth, alternately few branched. Leaves softly and closely puberulent on both surfaces, lanceolate, acuminate, 3.8-5.I cm. long, subsessile by an abruptly narrowed base, midrib white and prominently keeled beneath. Cymes terminal; bracts minute, grayish-tomentose, caducous; peduncles $2.5-5 \mathrm{~mm}$. long; involucres acutish at the base, dark purplish-red, I I $\mathrm{mm}$. long, glabrous without and within; tube: the lobes finely ciliated on the free margins; male pedicels and filaments glabrous, female pedicel glabrous; style slender, dark-red, trifid. Appendix 4-glandular, glabrous, abruptly bent, attenuate to a very narrow, truncate, entire or slightly retuse apex. Capsule smooth, $6.5^{-7} \mathrm{~mm}$. in length, upon a stipe $13 \mathrm{~mm}$. long; seeds ashen, ovoid, apiculate.

Type locality: Mexico, limestone ledges at La Palmas, San Luis Potosi, July 25, I891, Cyrus G. Pringle 5107. Type (visa) in herb.

Gray, Cambridge, Mass. 
Distribution: Mexico, Oaxaca, Pringle 6043; Nelson I682; Cäc. E。 Ed. Seler r682; Tomellin, Conzatti I672; Salina Cruz, Deam ir9. GuateMaLA, Gualan, Deam 234.

\section{Pedilanthus Smallii Millsp. sp. nov.}

Shrubby, $2 \mathrm{~m}$. high, profusely branching, the branches and branchlets more or less zig-zag (in the type very sharply and strongly so), branchlets slender, stipular glands plainly evident. Leaves densely crisp-puberulent when young, pubescent when developed, sessile, ovate-lanceolate to ovate, acute, the mid-rib inconspicuously keeled beneath. Inflorescence terminal on the young branchlets; bracts foliaceous, exceeding the peduncles, ovate-lanceolate, attenuate at the apex, crisp-pilose; involucres salmon to pink, glabrous without and within, I cm. $\times 4 \mathrm{~mm}$., superior fissure open to the appendix, inferior cleft shallow; main lobes of the tube ovate, rounded and ciliato-fimbriate on the margin, strongly folded into a plait along the margin of the fissure; lateral lobes free only at their rounded apices; fifth lobe free throughout, narrowly ligulate, obtuse. Male and female pedicels glabrous; male flowers about ro; style deeply 3-lobed. Appendix one third the length of the tube; lobe deltoid, not ciliate margined, retuse, strongly marked by a longitudinal channel as if nearing bilobation (in fact in one flower it was found to be deeply bilobed); glands 4 , in pairs the outer pair minute. Fruit unknown.

Type locality: Florida, in pine lands near Miami; John K. Small 2286, November, igo4. Type in the herbarium of the New York Botanical Garden. Full size photograph in herb. Field Museum.

Distribution: Bermuda, at Castle Point, Brown \&o Britton, 820,

September, I9I2.

8. Pedilanthus padifolius (L.) Poit. An. Mus. Paris, i9:39i. i8I 2.

Tithymaloides laurocerasi folio Dillen. Elth., t. 288. I732.

Euphorbia tithymaloides padifolia Linn. Sp. P1., 453. I753.

Euphorbia anacampseroides Lam. Dict., 2:420. I786.

Pedilanthus anacampseroides K1. \& Gke. Tricocc., I06. 1859.

Shrubby. Leaves glabrous, 9- $2 \times 3-5 \mathrm{~cm}$., subsessile, cuneate at the base, oblong-ovate, obtuse or retuse, keeled beneath. Cymes terminal, open; floral leaves ovate, acute; involucres large, sarcous, hairy within, $1.2 \mathrm{~cm}$. long; tube with the lateral lobes all spatulate and one third connate; male and female peduncles hairy; style entire at the apex the stigmatic point slightly marked with three shallow sulci. Capsule "the size of a hazel nut."

Type locality: Antillean Islands, Plumier. 
Distribution: Antillean Islands, Descourtils. Santo Domingo, Schomburgk I68. Sт. CRoIX, Ricksecker I8I; Mrs. Ricksecker I65. St. KrtTs, Britton \&o Cowell 256.

Illustrations: Descourt. Ant., t. I 7 ; Dillen. Elth., t. 288; Bot. Reg., t. 837; Bot. Mag., t. 254 .

9. Pedilanthus angustifolius Poit. An. Mus. Paris, 19:393, t. i9. I 8 I 2 .

Crepidaria subcarinata Haw. Rev. P1. Succ., 6I. I 82 I.

Crepidaria cordellata Haw. Rev. P1. Succ., I36. I82 I.

Euphorbia cordellata Haw. Misc. Natur., I85.

Pedilanthus cordatus Spr. Syst., 3:802.

Pedilanthus cordellatus. Steud. Nom., Ed. 2, 2:282. 1840.

Pedilanthus subcarinatus Steud. Nom., ibid.

Pedilanthus tithymaloides angustifolius pt. Griseb. Fl. Br. W. I., 52. I 859 .

Shrub I-I.3 m. Leaves pubescent, lanceolate, obtusely keeled beneath, $7-10 \mathrm{~cm}$. long, $1.5^{-2.5} \mathrm{~cm}$. wide. Cymes upper axillary and terminal; bracts ovate, pointed, longer than the peduncles; involucres strongly gibbous, somewhat puberulent, I cm. long; tube abruptly truncate, pubescent within; main lobes with ovate, entire, bluntpointed apices, the two lateral lobes connate to the apex, fifth lobe ligulate with a rounded apex and connate half its length; male and female pedicels hairy the male on the upper third. Appendix strongly gibbous at the base, the lip ligulate, emarginate, not thickened at the apex; glands 4 . Seeds strongly trigonal, $4.5 \times 3 \mathrm{~mm}$., sharply apiculate, dull ashen, the dorsal angle most prominent.

Type locality: Santo Domingo, Poiteau. Type in herb. Paris.

Distribution: Cuba, Wright. Santo Domingo, Poiteau; Ehrenberg.

Porto Rico, Garber I07; Sintenis 769; Britton \&o Shafer 1869. Culebra, Britton I 30 ; Britton \& Wheeler I 2 I. St. Croix, Ricksecker. JAMAICA, Grisebach.

Illustration: An. Mus. Paris, I 9:t.I9.

\section{Iо. Pedilanthus bahamensis Millsp. sp. nov.}

Shrubby, glabrous, I-I.5 m., leafless, * irregularly much branched, branches about the size of a lead pencil, gray, roughened with silicious

* I describe the plant as leafless from the fact that no Native has ever seen leaves on the plant even in the most prolonged rainy season; they all know, however, that a cutting will produce leaves if kept in water for a period of about three weeks. I thus produced leaves myself which were oblong-lanceolate, $2 \mathrm{~cm} . \times 8 \mathrm{~mm}$., rounded at the apex, somewhat narrowed to a sessile base, midrib keeled on the lower third, glabrous. (See sheet No. 288.150 in herb. Field Museum). 
transverse ridges. ${ }^{*}$ Inflorescence terminal on the branchlets; bracts cucullate, one third to one quarter the length of the peduncles. Involucres about $9 \mathrm{~mm}$. puberulent, bright and lasting madder-lake color; inferior cleft of the tube shallow, the superior fissure open half the length of the tube; main lobes blunt, finely erose-lacerate, the two lateral lobes minute, free only at the apex, the fifth lobe flabelliform, free half its length; male pedicels glabrous, slightly longer than the tube, anthers glabrous, female pedicel minutely puberulent, style very slightly trifid. Appendix narrow, about one half the length of the tube, sarcous, usually sigmoid, the lobe blunt, very slightly notched at the apex, strongly gibbous at the base; glands 2, stipitate, of the form of a ruptured 2celled anther. Capsule flattened-globose, deeply 3-carpelled; seeds trigonal, olivaceous, the dorsal angle quite prominent, apiculate and with a minute raised pimple at the apex, $3 \times 2.5 \mathrm{~mm}$.

Type locality: Grand Turk Island, on the rocky plain south of the town where it is one of the common shrubs, C.F. \& C.M. Millspangh 9030, February, I9II. Type in herb. Field Museum of Natural History, Chicago, sheet No. 287.782.

Distribution: The Bahama Islands from Deep Creek, Andros, to Atwood Cay, Acklin Island, Inagua, and Grand Turk to Salt CAY.

II. Pedilanthus Fendleri Boiss. in D. C. Prodr., I5:5. 1862.

Pedilanthus gritensis Zahlbr. An. K. K. Nat. Hofmus. Wien., I 2:104. I 897 .

Shrubby. Leaves $3.8-5 \mathrm{~cm}$. long, short petioled, puberulent at least beneath, cuneate at the base, acute, subcarinate. Cymes terminal, few-involucred, dense; bracts one half the length of the peduncles; involucre purple, $9 \mathrm{~mm}$. long, rusty-hairy without, smooth within; tube somewhat gibbous, the notch obtuse; main lobes rotund, lateral pair blunt-ligulate, connate except at the apex, fifth lobe ligulate, half free, rounded at the apex, all ciliate on the apical margin; male and female pedicels hairy on the upper two thirds; style trifid at the apex, the stigmatic lobes bifid. Appendix strongly ascending, one third the length of the tube, the ligulate lobe round-margined; glands 4 .

Type locality: Venezuela, Fendler I 202. Type (co-type visa) in herb. de Candolle, Geneva.

Distribution: Venezuela, Karsten. Colombia, H. H. Smith I295. Margarita Island, Miller \& Johnston $3 \mathrm{I}$.

* The peculiar silicious ridges of the stems and branches produce a high squeak when they are rubbed together - children play at fiddling with them, hence the local name "Monkey-fiddle." (The play of children being locally termed "monkey play.") 
I 2. Pedilanthus Grisebachii Millsp. \& Britton. sp. nov.

Pedilanthus angustifolius Griseb. pt. (non Poit.), F1. Br. W. I., $5^{2}$. I 859 .

Shrubby, I m. high, alternately branching, canescent above. Leaves canescent, narrowly lanceolate to linear, $\mathrm{I}-3 \mathrm{~cm}$. long, 3-4 $\mathrm{mm}$. wide, narrowed to the base, blunt at the apex, the midrib keeled beneath. Inflorescence terminal on the branches, few to several involucred; bracts small about half the length of the peduncles; peduncles hairy: .8-I cm. long; involucres small, 6.5-7 mm., canescent without, pubescent within; tube truncate at the apex, the main lobes broad, erose dentate; lateral lobes minute, spatulate, free only at the erose apex; the fifth lobe spatulate, fimbriate, connate two thirds its length; female pedicel slightly hairy at the base, style slightly 3 -cleft at the apex; male pedicels glabrous. Appendix strongly gibbous at the base, somewhat more than half the length of the tube, the lobe thickened and emarginate at the apex; glands 4. Capsule smooth, not strongly angled; seeds very slightly trigonal almost without angles, $3.5 \times 2.5 \mathrm{~mm}$., deep reddish-brown mottled with irregular, light maculæ.

Type locality: Jamaica, Bull Bay, on a roadside bank, N. L. Britton 3677, September I4, I9o8. Type in herb. New York Botanical Garden.

Distribution: Jamaica, Harris 9645. Porto Rico, Yauco, Underwood \& Griggs 637; Ponce, Heller 6192.

I 3. Pedilanthus articulatus (K1. \& Gke.) Boiss. in D. C. Prodr., I $5: 6$. I 862 .

Diadenaria articulata K1. \& Gke. Tricocc., I08. 1859.

Leaves $3.8-5 \mathrm{~cm}$. long, crisp-puberulent, sessile, shortly cuneate at the base, oblong, obtuse or retuse, ribbed-plicate. Cymes terminal, repeatedly dichotomous, its branches long and leafy, appressed hairy; floral leaves (bracts) longer than the involucres, ovate, puberulent, subcordate, cornucopia-shaped, mucronate; involucres central upon the peduncle, 2.8-r.4 cm.; tube glabrous without minutely and densely puberulent within, the superior fissure open to the appendix and the inferior notch to the peduncle; lobes all fimbriate, the main pair ovate, the lateral ligulateflabellate connate three quarters their length, the fifth free nearly throughout; male and female pedicels glabrous, filaments densely hairy. Appendix lobes deltoid, densely pubescent upon the inner surface, the terminal half revolute; glands 2 urceolate, long stipitate the lower half connate with the walls. Near P. Pavonis from which it differs in its obtuse, plicateleaves and the inflorescence characters. 
Type locality: Mexico, Pavon. Type (visa) in Herbarium Boissier, Geneva.

Distribution: Known only from the type.

14. Pedilanthus bracteatus (Jacq.) Boiss. in D. C. Prodr., I5:6. I 862 .

Euphorbia bracteata Jacq. Schoenb., 3:I4, t. $276 . \quad$ I 798.

Ventenatia bracteatus Tratt. Gen. P1. Disp., 87. $\quad$ I802.

Shrubby, I.20 m., branches scabrous leafless before flowering. Leaves smooth, $\mathrm{x}$ dm. long, subsessile, rounded at the base, oblong, obtuse or retuse, keeled beneath. Cymes terminal, repeatedly dichotomous, the articulations elongated, glabrous, leafy; floral leaves longer than the involucres, ovate, acuminate, concave, glabrous; tube of the involucre glabrous; lateral lobes linear, villous, shorter than the fifth lobe; pedicels and filaments glabrous; styles connate throughout. Appendix somewhat short, 4-glandular. Capsule subsphærical, 3-angled. Type locality: Mexico.

Distribution: Known only from the type.

Illustrations: Jacq. Schoenb., 3:t.276.

15. Pedilanthus spectabilis Robinson, Proc. Am. Acad., 43:23. I907.

Shrubby; stems.about 9 dm., terete, thick, leafy, gray. Leaves ovate-oblong, shortly and thickly petioled, $9 \mathrm{~cm}$. long, $3.8-6.3 \mathrm{~cm}$. broad, entire, smooth above, short and soft pubescent beneath, apex rotund, sometimes retuse, always mucronulate, slightly cordate at the base. Cymes terminal, dichotomous, densely bracteate, $16.5 \mathrm{~cm}$. broad; bracts broadly ovate, cordate, sessile, opposite, entire, $3.8-5 \mathrm{~cm}$. diameter, longer than the internode, acute or acuminate, extended into a tail, puberulous, purple-red, margin tomentellate; peduncles graytomentose on the lower half glabrous above; involucre white, $1.9 \mathrm{~cm}$. long the base slightly invaginate; the inferior notch extending nearly to the peduncle; main lobes shorter and broader, the other three ligulate, free nearly to the base, all erose at the apex and tomentellate on the margins; stipe of ovary smooth, nodding; filaments smooth; style 9.5 $\mathrm{mm}$. long; stigma unevenly 3-pronged; capsule subsphæric, about 9.5 $\mathrm{mm}$. in diameter, obtuse, 3 -lobed, each carple cornuate at the upper and lower dorsal ends; seeds grayish-green, angular, $5 \mathrm{~mm}$. long. Appendix deeply 2-parted, lobes linear, acute, about $18 \mathrm{~mm}$. long, much shorter than the tube, scaphoid, thickened and bi-laterally scutellate at the prow-shaped tips; 4-glandular, glands morchellæform. 
Type locality: Mexico, Iguala Cañon, on limestone ridges, alt. 2.500 ft., December 28, I906, Cyrus G. Pringle 13.9r4. Type (visa) in herb. Gray, Cambridge, Mass.

Distribution: Known only from the type.

\section{I6. Pedilanthus Greggii Millsp. sp. nov.}

Shrubby; stems ligneous, irregularly branching. Leaves oblonglanceolate, subsessile, about $9 \times 3 \mathrm{~cm}$., keeled beneath, finely puberulent, cuneate at the base, acute. Bracts large, including the involucres, ovate, broad, $1.5 \mathrm{~cm} . \times 8 \mathrm{~mm}$., rounded at the base acuminate at the apex, reddish; involucres $1.8 \mathrm{~cm}$. long, finely puberulent without pubescent within; tube truncate, the inferior cleft one third its length; main lobes broad, truncate, erose-dentate; lateral lobes ligulate, erose dentate, two thirds connate with the main lobes; fifth lobe similar but connate for only half its length; female pedicel short, glabrous; male pedicels unknown.* Appendix projecting backward in a sac, $9 \mathrm{~mm}$. long, deeply cleft into two ligulate lobes each of which is folded upon itself to the form of a canoe with a bifid prow; glands 2, large, deltoid, stipitate. Capsule depressed-globose shortly exserted; seeds trigonal, $5 \times 4 \mathrm{~mm}$., white-farinose, apiculate at both base and apex, angles prominent the dorsal most strongly so.

Type locality: Mexico, Dr. J. Gregg II56. Type in herb. Missouri

Botanical Garden, St. Louis, sheet No. I3.466.

Distribution: Known only from the type.

\section{I7. Pedilanthus Olsson-Sefferi Millsp. sp. nov.}

Shrubby; stems and branches succulent, hollow. Leaves short petioled, glabrous above densely crisp-puberulent beneath, $3^{-6} \times \mathrm{I}^{-5^{-2}}$ $\mathrm{cm}$., oblong to ovate, obtuse, midrib keeled beneath. Inflorescence terminal, cymose, puberulent; floral leaves oval, $4^{-2.5} \times 2-1.5 \mathrm{~cm}$., acute to acuminate, twice the length of the involucre and its peduncle; peduncles shorter than the breadth of the involucre. Involucre small, I X.5 cm., minutely puberulent especially at the base; tube thick; inferior notch half the length of the tube, superior fissure also half its length; main lobes oblong, the free margin minutely and evenly serrate; lateral lobes ligulate, truncate, serrate, connate at the lower third; fifth lobe ligulate, rounded and serrate at the apex, free to its base; male pedicels and filaments glabrous, anthers pilose; female pedicel pilose, style 6-cieft at the apex. Appendix half the length of the tube, sarcous, the lip deeply cleft into two ligulate, blunt lobes folded upon themselves like a trough, the margins and apices hairy; glands 2, large, cymbali-

*All destroyed by insect pests in the specimens seen. 
form, set closely facing each other at the base of the tube. Fruit unknown.

Type locality: Mexico, Tomellin, collected by the late Dr. Pehr Olsson-Seffer, August, I910. Type in herb. Missouri Botanical Garden, St. Louis, sheet No. I3. 465 .

Distribution: Known only from the type.

i 8. Pedilanthus involucratus (K1. \& Gke.) Boiss. in D. C. Prodr., I5:6. I862.

Diadenaria involucrata K1. \& Gke. Tricocc., I07. I8.59.

Shrubby, 9 dm.-I.2 m. Leaves petiolate (petioles $6 \mathrm{~mm}$. long), glabrous above, deflexed puberulent beneath, oblong, short-apiculate, $7.5 \mathrm{~cm}$. long, $4.2 \mathrm{~cm}$. broad. Cymes terminal bi-cephalic; bracts of the inflorescence puberulent, orbicular, apiculate, $2 \mathrm{~cm}$. long, r. $6 \mathrm{~mm}$. broad; involucres small, ro $\mathrm{mm}$. long; filaments glabrous.

Type locality: Mexico. Type a living plant in the Botanical Garden,

Berlin, I859.

Distribution: Known only from the type.

19. Pedilanthus Rubescens Brandegee, in Zoe, 5:209. 1905.

Stems numerous $\mathrm{I}-2 \mathrm{~m}$. high, much branched. Leaves nearly glabrous, ovate-lanceolate, cuneate at the base into a short petiole, midrib keeled and excurrent at the tip, $9 \mathrm{~cm}$. long, $3.5 \mathrm{~cm}$. broad. Cymes terminal, the floral leaves brick-red; involucres pubescent, cuneate at the base, $2 \mathrm{~cm}$. $\mathrm{x} 9 \mathrm{~mm}$., the inferior notch extending nearly to the base, the two main lobes oblong-oval, the two lateral narrow, linear, erose at the apex, connate four fifths their length, fifth lobe ligulate, truncate, erose-dentate; male and female pedicels glabrous, filaments glabrous; style nearly I $\mathrm{cm}$. long; capsule smooth, on a stipe I $\mathrm{cm}$. long, I $2 \mathrm{~mm}$. broad; seeds somewhat cuboid, apiculate, $5.5 \times 4.5$ mm., strongly 3 -angled the dorsal most prominent, reddish-brown, pulverulent (not pubescent). Appendix with two elongated-deltoid lobes thickened and compressed laterally at the bilobate apex, each with a large, phalloid gland at its base.

Type locality: Mexico, Culican, August 30, i904, T. S. Brandegee. Type (visa) in herb. University of California, Berkeley.

Distribution: Known only from the type locality where it was also collected by Dr. Edward Palmer in I89 I (his number I 767 in herb. New York.Botanical Garden).

20. Pedilanthus Palmeri Millsp. sp. nov.

Shrubby; stems hollow except at the nodes. Leaves broadly lanceolate-ovate, acute, narrowed to a cuneate base, glabrous, keeled beneath. 
Cymes trichotomous ultimately 3-cephalic; peduncles $\mathbf{I}-2 \mathrm{~cm}$. long, slender, finely puberulent; bracts $\mathbf{I} .5 \times .8 \mathrm{~cm}$., oval, acute, slightly exceeding the peduncles; involucres puberulent, $1.5 \times .6 \mathrm{~cm}$., the superior fissure closed to the throat by the connate lateral and fifth lobes; tube short, deeply notched beneath, projecting narrowly backward to support the long appendix; main lobes broader than long, the apex rounded, each with a projecting deltoid tooth connate with the lanceolate, acute, lateral lobes which, in turn, are connate with the ligulate, truncate, fifth lobe so that all together entirely close the usual superior fissure of the tube, all three minor lobes are free at their apices the fifth being slightly longer than the lateral; the notch of the tube has three to four raggedly-deltoid teeth at the base of its sulcus; male pedicels glabrous, female puberulent. Appendix as long as the tube, projecting posteriorly half its length and extending anteriorly along the margin of the fissure to the throat, split its entire length into two separate, linear lobes folded upon themselves upward like a trough; glands 4 , of two sorts, circular with raised thickened margin: two single ones placed flat against the walls of the gibbum, two double ones placed back-to-back at the summits of long stipes connivent with the walls at the base of the linear lobes (these latter resemble stamens with ruptured, 2-celled adnate anthers).

Type locality: Mexico, Tepic, I892, Dr. Edward Palmer 1995. Type in herb. New York Botanical Garden.

Distribution: Known only from the type.

21. Pedilanthus tomentellus Robn. \& Greenm. Am. Jour. Sci., 50:164. I 896 .

Tall, I. $5^{-2.4}$ m., rusty-tomentulose; branches stout, terete. Leaves short petioled, ovate-oblong to oblong-lanceolate, narrowed at both ends, obtusish, tomentulose upon both surfaces, $4.8 \mathrm{~cm}$. long, $2.4 \mathrm{~cm}$. broad. Cymes terminal, twice dichotomously forked, about $5 \mathrm{~cm}$. diameter, outer floral leaves and those of the forks large, bright red, sessile, broadly ovate or suborbicular, cordate, shortly acuminate, tomentulose, $2.4-3 \mathrm{~cm}$. long, enclosing the smaller bracts and the involucres thus giving the cyme a somewhat 2-cephalic appearance. Involucres $\mathrm{I} .2 \mathrm{~cm}$. in length, tomentulose throughout, unequally 5 -cleft at the throat the divisions rounded to sub-truncate with an erose or fimbriated margin, the three interior much smaller, linearoblong; pedicels of the staminate flowers glabrous, filaments and anthers pubescent; pedicel ovary and style of the pistillate flowers ferrugineous-tomentose; style $5 \mathrm{~mm}$. long the three divisions 2-cleft. Appendix deeply 2-cleft the lobes about $7 \mathrm{~mm}$. long, lanceolate, obtuse, thickened at the apex; glands 2 or 4 . 
Type locality: Mexico, Oaxaca, in hedgerows, alt. 5.500 ft., September 6, 1894, Cyrus G. Pringle 49г2. Type (visa) in herb. Gray, Cambridge, Mass.

Distribution: Known only from the type locality where it was also collected by Seler 1402; Chas. L. Smith 216, I I82; and E. W. Nelson I 20 I.

22. Pedilanthus Pavonis (Kl. \& Gke.) Boiss. in D. C. Prodr., I 5:6. I 862 .

Diadenaria Pavonis K1. \& Gke. Tricocc., I08. 1859.

Leaves large, I $2.5^{-17.5} \mathrm{~cm}$. long, $6.5^{-7.5} \mathrm{~cm}$. broad, subsessile, coriaceous, glabrous, rounded at the base, oblong, acute. Cymes terminal, many times dichotomous, compactly corymbose, closely hirsute; floral leaves ample, I.8-2. cm. long, longer than the involucres, oval, subcordate at the base, apiculate, persistent, puberulent. Involucres puberulent, I.6-I. $8 \mathrm{~cm}$. long; tube narrower than the appendix and scarcely longer, the main lobes fimbriate on the margins; pedicels of the male flowers filamentosely hairy. Appendix scarcely shorter than the tube, 2-glandular, the lip plainly inflexed with an evident fold beneath the apex within.

Type locality: Mexico, Ruiz \&o Pavon. Type (visa) in herb. Boissier, Geneva.

Distribution: Mexico, Colima, Palmer I328 (I89i).

23. Pedilanthus macradenius Donnell-Smith, in Bot. Gaz., i9:263. I 894 .

Arboreous; leaves glabrous, IO-I $5 \times 5-7.5 \mathrm{~cm}$., at the apex of the branches, olive-green, broadly ovate-oblong, obtuse at both base and apex; petioles glabrous, $6 \mathrm{~mm}$. long. Cymes short, few-involucred, springing from the upper axils; bracts oblong-ovate, longer than the peduncles, I $2 \times 6 \mathrm{~mm}$., rubescent beneath hoary pubescence; peduncles hairy; involucre rubescent, $\mathbf{I}-\mathbf{I} .5 \times .6 \mathrm{~cm}$., glabrous without, densely pubescent within including the lobes; superior fissure closed to the throat, inferior notch about one third the length of the tube; main lobes ovate, acute, long-hairy at the apex; lateral lobes free only at the spatulate, hairy apex; fifth lobe ligulate-spatulate hairy at the apex; male and female pedicels glabrous, bracteoles many, threadlike. Appendix nearly one half the length of the tube, cleft for about one third its length into two broadly ovate, flat lobes; glands 2, large, oval, flat. Capsules $8 \mathrm{~mm}$. diameter, depressed-spherical, marked with six broad white lines of dehiscence; coccules carinate; seeds trigonal-globose. 
Type locality: Guatemala, Canival, Huehuetenango, alt. $3.200 \mathrm{ft}$. December, I891, Dr.W.C. Shannon, U. S. A. 4I 2. Type (visa) in herb. Capt. John Donnell-Smith, in herb. U. S. National Museum, Washington, D. C.

24. Pedilanthus Oerstedii K1. \& Gke. Tricocc., io6. I859.

Branches virgate, leafless, terete, sparsely branchleted, long and stiffly puberulent. Cymes terminal; involucres solitary or few, peduncles glabrous.

(Said to differ from P. aphyllus only in the above characters). Type locality: Nicaragua, Segovia, Oersted. Type in herb. Botanical Museum, Copenhagen.

Distribution: Known only from the type.

25. Pedilanthus aphyllus Boiss. in Kl. \& Gke. Tricocc., ioo. 1859.

Pedilanthus calcaratus Schlecht. in Linnæa, I9:I55. I847. ex ref. et descr. pl. non visa.

Branches virgate, leafless, whitish, nearly simple. Cymes terminal; floral leaves deciduous; involucres single or in twos; peduncles pubescent; involucres $2 \mathrm{~cm}$. long (I.2-I.4 cm.); tube hairy within, deeply notched below, the main lobes rounded and erose-dentate at the apex, the two lateral lobes connate somewhat more than half their length and the fifth lobe one half connate with them, all spatulate, the rounded apices finely erose, ciliate; pedicels of the male and female flowers glabrous, the female bent strongly back toward the base of the involucre immediately upon its issuance from the tube, style at first entire at the apex later shortly 3cleft. Appendix about half the length of the tube and projected along its margin to the apex, prolonged posteriorly into a sarcous, 4-lobed, spurlike sac, its two lobes narrowly elongated-ligulate, blunt, emarginate; glands 4. (The italicized characters are drawn from Pringle No. 629I).

Type locality: Mexico, Ruiz \&o Pavon. Type in herb. Boissier, Geneva. Distribution: Mexico, Orizaba, Botteri 968; Tehuacan, Puebla, MacDougal \& Rose, Pringle 629I, Purpus 34I9, Rose \&o Rose; Liebmann (P. calcaratus $\mathrm{Schl}$.).

26. Pedilanthus nodiflorus Millsp. Field. Col. Mus. Bot., i :305. I 896 .

Shrubby, $2 \mathrm{~m}$. high; stems whitish-farinose, jointed, widely branching; branches virgate, alternate, leafless. Inflorescence in lateral, spiciform, densely white-tomentose cymes at the nodes. Involucre red, hairy without and within, $8 \times 4.5 \mathrm{~mm}$., the superior fissure closed by the united lateral and fifth lobes, the inferior notch about half the 
length of the tube; main lobes truncate, erose-dentate, overlapping to form an oval orifice of the sinus; lateral and fifth lobes ligulate, free at the apex, equal, truncate, the lateral connivent with the edges of the fissure; the fifth lobe keeled, all saccate at the base; male and female pedicels glabrous; young capsule hairy. Appendix nearly as long as the tube, 2-saccate and 2-glandular at the base, deeply bi-lobed, the lobes narrowly ligulate, unequally. 2 -digitate, appearing like an extended and apposed thumb and forefinger of a human hand.

Type locality: Mexico, Yucatan, Silam, abundant about the port, April, I895, Dr. George F. Gaumer 649. Type in herb. Field Museum

Natural History, Chicago; sheet No. 36.452.

Distribution: Mexico, Yucatan, Progreso, Millspaugh 1667.

Illustration: Field. Col. Mus. Bot., I:pl.I7.

27. Pedilanthus cymbiferus Schlecht. in Linnæa, I9:253. I847.

Branches crispid-hairy; leafless. Cymes . . . ; peduncles glabrous, $8 \mathrm{~mm}$. long; involucres glabrous, $1.2 \mathrm{~cm}$. long; tube with the inferior notch $4 \mathrm{~mm}$. deep; main lobes equal, rounded and finely serrate at the apex; lateral lobes connate to near the obtuse, serrate apices, pubescent without; fifth lobe spatulate; male and female pedicels glabrous; ovary glabrous; style $6 \mathrm{~mm}$. long, shortly 3-cleft at the apex. Appendix sarcous the gibbous portion warty-tuberculate without and closely puberulent within including the lip; lobes ligulate, $6 \mathrm{~mm}$. long, obtuse; glands unknown.

Type locality: Mexico, Liebold 213. Type in herb. University of Kiel, Germany.

Distribution: Known only from the type.

28. Pedilanthus macrocarpus Benth. Bot. Voy. Sulph., 4 :t.23, f. A. I 844 .

Hexadenia macrocarpa K1. \& Gke. Tricocc., I07. I859.

Shrubby; $9 \mathrm{dm}$. high; dichotomously branching; branches terminal, thick, fleshy, articulated by constriction. Leaves of the stem unknown. Cymes lax, few-flowered; floral leaves or bracts minute, 6-8 mm., cucullate, one quarter the length of the peduncle; peduncles shorter than the involucres; involucres $1.8-3.2 \mathrm{~cm}$. long $(2.3 \times \mathrm{I} \mathrm{cm}$.) the peduncle central on the tube; tube plainly gibbous, 4-lobed (sic.) the superior fissure closed to the throat, the inferior notch shallow; main lobes orbicular and erosedentate at the apex; lateral and fifth lobes narrowly linear and connate into a trefoil at their apices where only they are free, apices flabellate, ciliate; male flowers ligulo-bracteolate, the pedicels with that of the female flower glabrous; styles bi-lobed at the apex; capsule large, fleshy, $2.4 \mathrm{~cm}$. 
(including the horns), 3-carpellate (one aborted in all specimens seen); carpels each prolonged downward into two conical horns; seeds globoselenticular, $7.5 \mathrm{~mm}$. diameter, rusty-brown, smooth, apiculate. Appendix fleshy, slightly shorter than the tube (usually about one half its length), deeply cleft into two ligulate, laterally compressed, bi-geniculate lobes turned upward at the rounded apex; glands 8 (often by abortion 6) in two sets of four each at the bases of the lobes. (Characters in italics drawn from the Palmer, Agiabampo plant).

Type locality: Mexico, Lower California, Magdalena Bay, Hinds. Type in herb. Kew, England.

Distribution: Mexico, Agiabampo, Palmer 802 (I89o); Manzanillo, Palmer 802 (I89I); Magdalena Island, Brandegee; E1 Lano de Santana, Brandegee; Los Angeles Bay, Palmer 604, 605 (I887).

Illustrations: Bot. Voy. Sulph., 4:t.23, f. A.

\section{Pedilanthus peritropoides Millsp. sp. nov.}

Shrubby, glabrous. Leaves sessile, I 2-I $5 \mathrm{~cm}$. long, 5-6 cm. broad, thin, ample, glabrous, oblong to ovate, rounded and often emarginate at the apex, cuneate at the base, the midrib keeled for its lower third beneath. Inflorescence terminal, cymose, crisp-pubescent, bracteate; bracts oval, pointed, r. $8 \times 1.5 \mathrm{~cm}$., as long as or slightly longer than the peduncles. Involucre $2 \times \mathrm{I} \mathrm{cm}$. crispidulous-puberulent without, glabrous within, the tube broad and truncate anteriorly; main lobes ovate, pointed, entire; the three accessory lobes short, flabellate, equal, free at the ciliate apex only; male pedicels numerous, glabrous; female crisppuberulent throughout; style 3-parted at the apex, stigmatic branches bi-lobed. Appendix small, about one third the length of the tube, its lobes entirely concealed within the wing-margined fissure of the tube; lobes 3 , the superior pair ligulate, the margins folded upward upon themselves like a trough, the third lobe elongated-linear with a deltoid base, all crisp-puberulent; glands 4 at the gibbum: one pair at the inner bases of the superior folded lobes the other pair on the walls of the gibbum beneath the base of the third lobe.

The involucres, with their large, rounded anterior end, appear as if reversed from their usual form, the posterior exactly resembling the usual anterior extremity. The male flowers are exserted upward in a plumelike fascicle from the fissure instead of forward, as usual, along the female pedicel.

Type locality: Mexico, Coahuayula, Michoacan, Dr. G. M. Emrick 8o, November, I902. Type in herb. Field Museum of Natural History, Chicago; sheet No. 200.4I6.

Distribution: Known only from the type. 


\section{Field Museum of Natural History-Botany, Vol. II}

30. Pedilanthus Itzaus Millsp. Field. Col. Mus. Bot., i:305. I896.

Shrubby, glabrous, I.5 m. high; branches virgate, strongly zig-zag, succulent. Leaves sessile, sarcous, ovate, acute, deltoid at the base, $5^{-7.5} \times 4^{-6} \mathrm{~cm}$., mid-vein prominent beneath, lateral veins nearly at right angles. Inflorescence terminal, I or 2 involucred; involucres glabrous, light-pink, I cm. x $3.5 \mathrm{~mm}$., superior fissure open three quarters the length of the tube; inferior notch shallow; main lobes rounded; lateral lobes comparatively large, ovate, one third free; fifth lobe ligulate, free two thirds its length, truncate; all ciliate; male and female pedicels glabrous. Appendix small, about one third the length of the tube, 3-lobed, 4-glandular, lobes deltoid at the base, the central truncate, notched, the two lateral triangular, acuminate, shorter. Style 3-cleft, the divisions 2-lobed.

Yaxhalalche. Also cultivated for ornamental purposes and used in domestic medicine. The Mayas consider the plant very poisonous. They use quarter drop doses, in water, as a certain and effectual purgative.

Type locality: Mexico, Yucatan, Silam, March to June, Dr. Geo. F.

Gaumer 452. Type in herb. Field Museum of Natural History, Chicago, sheet No. 36.255 .

Distribution: Mexico, Yucatan, Merida, Dr. Arthur Schott $55^{2}$ (in herb. Field Museum); Porfirio Valdez 85. CuBA, Britton, Britton E Shafer I56. Santo Domingo, Wright, Parry \&o Brummel. Illustration: Field Col. Mus. Bot., I:t.I8.

$\S C A L C E O L A S T R U M$ : Involucre bilabiate, gibbous at the base of the superior lip. Superior lip (appendix) large, anteriorly curved, shoe-shaped, inflated, compressed, orbicular, opening by a small rounded aperture at the base, 4-glandular internally. Lower lip (tube of the involucre) short, urn-shaped; lobes 5 , short, somewhat connivent, ciliate; inferior pair ovate, three to four times broader, superior oblong, scarcely shorter. Floral bracts none. Ovary not cup-shaped. Differs from Eupedilanthus in the following characters: shrubs with glanduliform stipules; upper-lip (appendix) ample and shoe-shaped, the anterior and posterior facies compressed.

31. Pedilanthus Finki Boiss. in D. C. Prodr., i5:I261. 1866.

Shrubby; stems smooth, hollow except at the nodes. Leaves subsessile, oblong, IO-I4 cm. long, the base long-attenuate, apex acute and bearing a dark, cormuous mucron; midrib prominently keeled beneath. Cymes terminal, often twice-dichotomous, branching from the base, 
I0.2-1 $2.7 \mathrm{~cm}$. including the peduncles; floral bracts oblong-lanceolate, acute, slightly puberulent, as long as the puberulent peduncles, not early deciduous; peduncles but slightly exceeding the involucres; involucres obconic at the base, $\mathrm{r} .3 \mathrm{~cm}$. long, $9 \mathrm{~mm}$. broad, the appendix and tube nearly parallel, beautifully roseate or greenish, or the appendix roseate while the tube is greenish; tube thin; male and female pedicels glabrous; style long-exserted, very slender or threadlike, deeply cleft into three lobes at the apex. Appendix calceolate, dorsally concave with a rounded margin, $3.5 \mathrm{~mm}$. broad, thicker than the tube; glands circular, flat, thick rimmed. (Characters in italics are drawn from plants grown in the Missouri Botanical Garden).

Type locality: Mexico, Cordova, Finck. Type in herb. Kew, England. Distribution: Known only from the type and from a plant brought by the Mexican Commission to the Louisiana Purchase Exposition, St. Louis, in 1904, from which cuttings were grown in the Missouri Botanical Gardens up to 1907 ; of this plant there is a herbarium sheet in the herb. Missouri Botanical Garden and in herb. Field Museum of Natural History, through the courtesy of the Director of the Garden.

\section{SPECIES NON SATIS NOTA.}

Pedilanthus Houlletii Baill. Adansonia, r:34r. r86r.

The description of this species was drawn from a plant cultivated for several years in the gardens of M. Houllet, Paris. I am not certain that a herbarium specimen was preserved. No nativity of the original plant is recorded in the description.

Pedilanthus Ghiesbreghtianus Baill. Adansonia, r:340. r86r.

A species credited to Mexico but with insufficient description to satisfactorily establish its status.

\section{CUBANTHUS Millsp. Gen. nov.}

Pedilanthus Sectio Cubanthus Boiss. in D. C. Prodr., 15:7. I862.

Involucre equal, urn-shaped, the apex (throat) constricted, truncate, minutely and irregularly denticulate-erose, erect upon the peduncle; appendix a concave, glandular disk upon the middle of the dorsum; peduncle jointed and bearing two leafy bracts; fruiting pedicel strictly erect; bracteoles numerous.

This genus apparently joins Pedilanthus to Euphorbiodendron, to the 
latter its species bear great general resemblance in being small trees bare of leaves except at the apices of the young branches and in bearing its glandular appendix on the outer wall of the involucre.

Type species: Pedilanthus linearifolius Griseb.

Bracteoles glabrous; branchlets slender

r. linearifolius

Bracteoles hairy; branchlets thick and stubby

2. Brittoni

C. linearifolius (Griseb.) Millsp. comb. nov.

Pedilanthus linearifolius Griseb. Wright Cub., in Mem. Am. Acad., I860: I6r.

Leaves elongate, linear, attenuate at the base, acuminate, the midrib keeled throughout. Cymes terminal, 2-several cephalic, umbellulocorymbose, shorter than the leaves, the peduncles jointed and bearing two ovate, acute, leafy bracts nearly equaling the involucre. Styles connate to the apex.

A shrub or small tree appearing much like a Euphorbiodendron or Thevetia neriifolia. Branches smaller than a goose quill, the younger ones leafy or leaf-scarred throughout. Leaves $2.5^{-10} \mathrm{~cm}$. long, 2-3 $\mathrm{mm}$. wide, margin sub-revolute, the midrib whitish and keeled beneath, glabrous. Branchlets $3-5 \mathrm{~mm}$. thick ( $p l$. sicc.), bark reddish-brown, striate. Appendage more or less scutellæform, sessile, ovate, the margin corrugate. Male flowers numerous, subincluded, pedicels glabrous, bracteoles numerous, glabrous; female pedicel long exserted, strictly erect; capsule $6 \mathrm{~mm}$. long, transversely anastomose-wrinkled; calycle small, acutely 3 -lobed, lobes minutely deltoid, acuminate; seeds cylindro-lenticular, buff, hilum dark brown, $4.2 \times 3.7 \mathrm{~mm}$. Peduncles in fruit $2 \mathrm{~cm}$. long. Involucres $5.1 \mathrm{~mm}$.

Cuba: Farallones, N. Sophie, Wright No. I677, Nov. I2, I859. Type (visa) in Herbarium Gray, Cambridge, U. S. A., type photograph in Herb. Field Museum. Pitajones, Province of Santa Clara, Shafer No. I2.194, I2.200, February 28, I9I2.

\section{Brittoni Millsp. sp. nov.}

Leaves . . . Branches and branchlets thick ( $p l$. sicc.) short and stubby; leaf scars crowded at the apex only; bark yellow or coppery, smooth. Peduncles in fruit $\mathrm{I} \mathrm{cm}$. long; involucres $6.1 \mathrm{~mm}$. long; appendix more or less rectangular, thickened and glandular below; bracteoles hairy. Ripe capsules $4 \mathrm{~mm}$. long; seeds globose-lenticular, olivaceous, hilum yellowish, $4 \times 3.8 \mathrm{~mm}$.

The species as so far known is without leaves, young involucres and leafy bracts, it is, however, strongly differentiated from the preceding 
in its thick, stubby, much more numerous branchlets; its larger involucres and shorter peduncles; its hairy bracteoles and its seeds.

Cuba: Rio San Juan, Province of Santa Clara, rocky hillsides, Britton, Earle E。 Wilson No. 5874, March 24, I9ro. Type in Herbarium New York Botanical Garden.

EUPHORBIODENDRON Millsp. Field. Mus. Bot., 2:305. r9o9.

\section{Euphorbiodendron Shaferi Millsp. sp. nov.}

Shrub or small tree $3-3.3 \mathrm{~m}$. high, profusely branching; branches divaricate, leafy and leaf-scarred at the apex only; bark finely transverse fissured. Leaves glabrous, coriaceous, oval, short petiolate, $2-3 \times .8$ $\mathrm{cm}$., slightly narrowed at the base, apiculo-mucronate, the midrib prominent and somewhat keeled on the lower third. Inflorescence solitary at the apex of the young branchlets; floral leaves 2, opposite, brilliant red, orbicular, $1.4 \mathrm{~cm}$. diameter, apiculate. Involucre turbinate, subsessile, $5 \times 6 \mathrm{~mm}$., glabrous, papillate without hairy at the throat within; lobes various, mostly ligulate and irregularly 3 -toothed, some deltoid, thin and fimbriate; glands marginal, oval laterally compressed to scaphoid; bracteoles many, threadlike, hairy; female pedicel glabrous, style 3= lobed, the lobes revolute. Fruit unknown.

Type locality: CubA, vicinity of Camp San Benito, Oriente, alt. 900 m., in a thicket along the rocky river; collected by J. A. Shafer 4078,

February 24, rgro. Type in herb. New York Botanical Garden.

Distribution: Known only from the type.

\section{Euphorbiodendron linearifolium Millsp. sp. nov.}

Tree $5 \mathrm{~m}$., profusely branching; branches ascending, leafy and leafscarred at the apex of the young branchlets only; bark silvery-white to light coppery-brown, coarsely transverse fissured. Leaves sessile, linear, pointed, only slightly if at all narrowed at the base, thick, glabrous, olive-green, I.5-4 cm. long, I.5-3 mm. broad, the midrib light colored and keeled beneath. Inflorescence solitary at the apex of the new branchlets; floral leaves or bracts bright scarlet, orbicular-ovate, r. $8 \times 2.2 \mathrm{~cm}$., pointed. Involucre cupulate, $4 \times 6 \mathrm{~mm}$., glabrous without and within, thick, sarcous; lobes small, flat, with three thick, sarcous, blunt, finger-like teeth; glands oval, laterally compressed to scaphoid; flowers surrounded by 5 oval, fimbriate bracts enclosing a mass of ligulate-fimbriate bracteoles and a few (about ${ }^{5}$ ) male flowers; female pedicel glabrous; style short, 3-lobed. Fruit unknown. 


\section{Field Museum of Natural History-Botany, Vol. II}

Type locality: Cuвa, Oriente, Sierra Nipe, along trail Piedra Gorda to

Woodfred; in dry rocky thickets serpentine formation, alt. $400-500 \mathrm{~m}$.

Collected by J. A. Shafer 3092, December 8, 1909. Type in herb.

New York Botanical Garden.

Distribution: Known only from the type.

\section{DENDROCOUSINSIA Millsp. gen. nov.}

Flowers diøcious, apetalous; disk none. Female flowers: calyx cupuliform, fleshy, sepals 3 , minute, each basally subtended (internally) by a bract fringed with filamentous glands, ovary 3-celled, stigma 3branched. Male flowers diskless, stamens 3 with 2-celled anthers opening by a longitudinal fissure, calyx lobes three, each subtended (internally) by a minute bract with a glandularly fringed margin. Capsule tricoccous, seeds carunculate.

Trees with thick, coriaceous leaves alternate below opposite or faciculate above, the lateral veins evident and tipped with a minute gland when ending at the margin of the leaf; inflorescence in terminal spikes or clusters, the male and female flowers sessile or appearing so, minute, diskless, each accompanied by two flanking glands.

Near Sebastiania. Dedicated to the Hon. H. H. Cousins, M. A., F. C. S., Director of the Department of Agriculture of Jamaica.

Flowers spicate, leaves petiolate

Flowers fasciculate, leaves sessile
I. D. spicata

2. D. fasciculata

\section{Dendrocousinsia spicata Millsp. sp. nov., typus gen.}

A small tree. Leaves alternate below, often opposite upon the flowering branchlets, glabrous, pale-green, thick, coriaceous, $4.5^{-8} \mathrm{~cm}$. long, $3-4.5 \mathrm{~cm}$. broad, oval to orbicular, blunt or slightly emarginate; margin entire, revolute ( $p l$. sicc.) and pitted with very minute glandular dots; midrib prominent beneath; lateral veins generally opposite and substantially at right-angles to the mid-vein; petioles about $5 \mathrm{~mm}$. long; stipules discoid-glandular. Inflorescence in terminal spikes, the flowers flanked on each side by a nearly globular gland pitted centrally; male spikes glabrous, slender, elongated, about ro $\mathrm{cm}$., the flowers glabrous, sessile upon a nodular prominence; stamens 3 , divaricate, contiguous at the base, filaments rigid, anthers bilocular opening with an erose margin; calyx lobes oval, alternate with the filaments, involute to the appearance of a cup, apex generally acute, erose; internal basal bracts deeply fringed into $5^{-7}$ glandular filaments. Female spike shorter, about $4 \mathrm{~cm}$., 
flowers subsessile; calyx cupulate, lobes 3, scaphoid-ovoid, sarcous, margin erose, internal bracts as in the male; ovary 3-celled; stigma sessile, the three branches divaricate, lying closely appressed to the ovary and incurved at the tips. Capsule glabrous, $5 \mathrm{~mm}$. diameter, strongly 3 -coccous, the cocci rotund, but slightly keel-marked and minutely transverse wrinkled; seeds light brownish-gray, elongated-ovoid, $5 \times 3.5 \mathrm{~mm}$., smooth, caruncle flattened-discoid, umbonate, chartaceous. Sap watery. Type locality: Jamaica, Upper Clarendon, Peckham woods, on limestone rocks at $8.5 \mathrm{~m}$. altitude. Collected by $W m$. Harris ro,980; I0,98I; II.204, July to September, I9II. Types in herb. Field Museum of Natural History, sheets Nos. 376.686 (male), 376.685 (female), 376,690 (fruit collected from the same tree as the female flowering specimens, September 9, I912).

Distribution: Known only from the type locality.

\section{Dendrocousinsiả fasciculata Millsp. sp. nov.}

A small tree, $5 \mathrm{~m}$. Leaves alternate below, opposite and fasciculate (appearing trifoliate) above, gray-green, glabrous, $3^{-9} \mathrm{~cm}$. long, I.5-5 $\mathrm{cm}$. broad, ovate to oval, coriaceous, reticulate-veined, rounded at the apex, margin slightly and irregularly wavy dotted with a few minute, glandular points; mịdrib prominent and yellowish beneath, the lateral veins irregularly disposed and ascending; stipular glands on each side - of the base of the midrib. Inflorescence (female) in sessile, crowded fascicles at the apex of the terminal branchlets surrounded by the fascicle of leaves. Female flowers subsessile, roseate; calyx cupulate, lobes oval, narrow, margin irregularly 3 -toothed, teeth broad, erose; internal basal bracts short-lacerate-glandular; basal glands antler-like with one, two or three prongs, their bases connected by an oval, erosemargined, bractlike scale; branches of the style appressed to the ovary, not incurved at the tips. Fruit and male flowers unknown. Sap milky. Type locality: JAmaica, Westmoreland and Hanover, in woods at the summit of Dolphin Head, alt. $690 \mathrm{~m}$. Collected by N. L. Britton 2219, March 18-20, 1908. Type in herb. New York Botanical Garden.

Distribution: Known only from the type and Harris 10,266 gathered from the same tree. 
CHAM ESYCE S. F. Gray, Nat. Arr. Brit. P1., 2:260. I82 I.

\section{( HY PERICIFOLI E)}

\section{Chamæsyce Lansingii Millsp. sp. nov.}

Hirta, ad rami pilis canescentes ad folii longe et sparse pilosi; prostrata alternatim pauci ramoso; foliis brevissime petiolatis e basi oblique, oblongo-ovatis, acutis, margine acute et plene serratis, stipulis deltoideis. Involucri pauci ad basi foliis supremis, longe pedunculatis, anguste turbinati extus glabri intus ad fauci longe pilosi, lobis integris (excepta duo ad sulci lace ratis), triangularis in ligula prolongatis, glandularum appendice ovata, alba crebro roseo coloratis, integris. Capsulæ glabræ, coccis minus carinatis; semine nigroargenteus ovoideo-quadrangulatis minute et transverse anastomosorugulosis.

Plants rather firm stemmed, branches lurid, appressed-downy, $2-3$ dm. long, internodes about $2 \mathrm{~cm}$., leaves $\mathrm{I} .2-\mathrm{r} .8 \mathrm{~cm}$. long, 6-8 $\mathrm{mm}$. broad, petioles $\mathrm{I} .5^{-2} \mathrm{~mm}$. long, seeds $\mathrm{I} .2 \times .9 \mathrm{~mm}$. Inflorescence solitary in the axils.

Type locality; Illinois. Collected by Odell E. Lansing, $J r$., in paved ditches of Chicago streets, August 6, I898, No. 402. Type in herb. Field Museum of Natural History, Chicago, sheet No. 196.668. Mr. Lansing re-collected the plant in the original locality in I908, finding the plants. persisting in all characters.

Distribution: Illinois and Wisconsin to Massachusetts and southward.

Chamæsyce Rothrockii Millsp. sp. nov.

Glabra, caule erecto, simplici vel alternatim ramoso, teretis, internodiis elongatis; foliis brevissime petiolatis e basi oblique, oblongoovatis, acutis, margine serratis; stipulis triangulatis ad apice laceris; cymis pauci floralis, terminalibus foliis supremis basi suffultis, involucri anguste-turbinati extus et intus glabri, lobis integris, triangularis in ligula prolongatis, glandularum appendice alba plus minusve rudimentariis, albis, ovalis, integris. Capsulæ glabræ; coccis carinatis; semine fusco-olivaceus, ovoideo, quadrangulis, transverse anastomosorugulosis.

Plants firm stemmed, branches terete, ligneous, 3-4 dm. long, internodes $3-5 \mathrm{~cm}$. long; leaves $\mathrm{I}-\mathrm{I} .5 \mathrm{~cm}$. long, $.5^{-} .8 \mathrm{~cm}$. broad; petioles ${ }_{2-3}-3 \mathrm{~mm}$. long; inflorescence $2-6$ flowered; seeds $\mathrm{r} .3 \times .8 \mathrm{~mm}$. 
Type locality: Arizona. Collected by Dr. J.T. Rothrock in 1874 , his number 872 of the Wheeler Expedition. Type in herb. Field Museum of Natural History, Chicago; sheet No. I97.499.

Distribution: Mexico, Culiacan, I891, Dr. Edwd. Palmer I5I7.

Chamæsyce glomerifera Millsp. sp. nov.

Glabra, caule erecto simplici vel alternatim ramoso, purpurascento, foliis brevissime petiolatis e basi oblique auriculatis, oblongo-ovatis, obtusis, margine plane serrulatis; stipulis rubellis, carnosis, triangularibus, indivisis. Cymis densiuscule glomeratis, terminalibus foliis supremis basi suffultis; involucri anguste turbinati extus et intus glabri, lobis fimbriatis, glandularum appendice alba, ovato-rotunda eis latiori integra; stylis brevibus dimidiatus bifidis. Capsulæ glabræ coccis manifeste carinatis; semine roseus ovato-tetrangulo transverse anastomosoruguloso.

Plants heavily stemmed; branches terete, ligneous, $2-3 \mathrm{dm}$. long, purplish; internodes $8 \mathrm{~cm}$. long; leaves $2.5-3.5 \mathrm{~cm}$. long, $1.5^{-2} \mathrm{~cm}$. broad; petioles about $3 \mathrm{~mm}$. long; glomerules $2-2.5 \mathrm{~cm}$. broad; seeds I $\mathrm{mm}$. long, .7 $\mathrm{mm}$. broad.

Type locality: Guatemala. Collected by the late Dr.W. A. Kellerman, January 20, I908, No. 8053. Type in herb. Field Museum of

Natural History, Chicago; sheet No. 224.827.

Distribution: Known only from the type.

ADENOPETALUM Kl. \& Gke. Tricocc., 47. I859.

Adenopetalum Barnesii Millsp. sp. nov.

Caule brevi duriusculo alternatim ramosissimo, ramis tenuis filiformis glabris ad apice umbelliformis; foliis minimis petiolatis orbiculatis acutis barbulato-hirtis; stipulis obsoletis; involucris terminalibus pedunculatis extus barbulatis intus glabris, lobis deltoideis erosis, glandulis minutis ovalis concavis, appendice quinquepartita laciniis digitoideis glandula multo longioribus; stylis bipartitis. Seminibus griseis ovatis profunde sculptis ad angulos fovearum albotuberculatis.

A low, erect, spreading plant $\mathrm{I} 3^{-\mathrm{I}} 6 \mathrm{~cm}$. high, $4^{-\mathrm{I} 2} \mathrm{~cm}$. broad with all characters minute; internodes $\mathrm{I}-3 \mathrm{~cm}$. long; leaves $3^{-6} \times 1.55 \mathrm{~mm}$., petioles about one half the length of the blade; seeds $.8 \times .4 \mathrm{~mm}$.

Type locality: Mexico, Jalisco, along the road to San Domingo Mine near Etzatlan. Collected by the late Dr. Charles Reid Barnes and

Dr. W. J. G. Land 306, October 6, 1908. Type in herb. Field

Museum of Natural History, Chicago, sheet No. 247.472.

Distribution: Known only from the type. 


\section{II-TWO NEW STONECROPS FROM GUATEMALA}

\section{By RAYMOND HAMET.}

Sedum Millspaughi Raymond Hamet, sp. nov.

Planta perennis? Radices . . Caules floriferi erecti, robustiusculi, glabri. Folia alterna, glabra, sessilia, infra insertionem in calcar non producta, plana, obovata, marginibus integerrimis, apice acutiuscula, longiora quam latiora. Inflorescentia laxa, in cymis uniparis et raro biparis. Bractæ alternæ, sessiles, infra insertionem in calcar non producta, ovatæ, marginibus integerrimis, apice acutiusculæ, glabræ, longiores quam latiores. Pedicelli calyce paulo breviores, glabri. Calyx glaber, segmentis 5 , infra insertionem in calcar non productis, suboblongis, marginibus integerrimis, apice acutiusculis longioribus quam latioribus. Corolla glabra, calyce paulo longior vel paulo brevior, segmentis 5 , tubo multo longioribus, obovatis, in parte inferiore attenuatis, marginibus integerrimis, apice acutis et aristatis, arista petali apicem superante, longioribus quam latioribus. Stamina ro; filamenta omnia longe lineari-deltoidea, glabra, oppositipetala infra corollæ medium inserta; antheræ suborbiculares, basi et apice emarginatæ, tam longæ quam latæ vel paulo latiores quam longiores, oppositipetalæ corollæ medium superantes sed petalorum apicem non attingentes. Carpella 5, multiovulata, glabra, in stylos carpellis breviores attenuata, placentis a gracili ligamine secundum carpellorum margines disposito constitutis, apice obtusæ, longiores quam latiores. Folliculi 5, multiseminati, erecti, lateribus internis non gibbosis. Semina testa duabus extremitatibus nucleum non superante.

Caulibus floriferi I I-I $3 \mathrm{~cm}$. longi. Folia $25 \mathrm{~mm}$. longa, $9.50 \mathrm{~mm}$. lata. Bractæ $4.50 \mathrm{~mm}$. longæ, r.60 mm. latæ. Pedicelli $4 \mathrm{~mm}$. longi. Calycis pars concreta $0.75^{-1} \mathrm{~mm}$. longa, pars libera $4.20-5.75 \mathrm{~mm}$. longa, I.30-2.25 mm. lata. Corollæ pars concreta $0.30 \mathrm{~mm}$. longa, pars libera $4.75-5.50 \mathrm{~mm}$. longa, $2.30-2.50 \mathrm{~mm}$. lata. Staminum alternipetalorum pars concreta $0.30 \mathrm{~mm}$. longa, pars libera $2.20-2.25 \mathrm{~mm}$. longa, $0.30 \mathrm{~mm}$. lata; staminum oppositipetalorum fiamentorum pars concreta I mm. longa, pars libera I.75-I.80 mm. longa, $0.20 \mathrm{~mm}$. lata. Antheræ $0.50 \mathrm{~mm}$. longæ, $0.50-0.60 \mathrm{~mm}$. latæ. Carpellorum pars concreta $0.50-0.60 \mathrm{~mm}$. longa, pars libera $1.75^{-2} \mathrm{~mm}$. longa. Styli $0.75^{-}$ $0.80 \mathrm{~mm}$. longi. Squamæ $0.80 \mathrm{I} \mathrm{mm}$. longæ, $0.40-0.50 \mathrm{~mm}$. latæ. 
Guatemala, Depart. Amatitlan, Laguna (Lake Amatitlan); alt. I 200 m.; 25 January, I906 [W. A. Kellerman No. 6559-typus in herb. Field Museum of Natural History, Chicago; sheet No. 220.889].

Sedum Triteli Raymond Hamet sp. nov.

Planta perennis. Radices fibratæ. Caules basi subrepentes et steriles caules edentes, deinde erecti et simplices, glabri et papillosi. Folia alterna, sessilia, infra insertionem in calcar non producta, obovato, sublinearia vel obovato, suboblonga, integra, glabra, apice obtusa vel obtusiuscula, longiora quam latiora. Inflorescentia biflora. Bractæ foliis similes sed eis minores. Pedicelli calyce breviores, glabri. Calyx glaber, segmentis 5 , tubo longioribus, infra insertionem in calcar non productis, longe lineari-deltoideis, basidilatatis, marginibus integerrimis, apice obtusiusculis, longioribus quam latioribus. Corolla glabra, calyce longior, segmentis 5 tubo multo longioribus, suboblongis, marginibus integerrimis, apice obtusiusculis, dorso subcarinatis, carina petali apicem non superante, longioribus quam latioribus. Stamina ro; filamenta omnia longissime lineari-subdeltoidea, glabra, oppositipetala infra corollæ medium inserta; antheræ subovato, reniformes basi emarginatæ, apice obtusæ, tam longe quam latæ, oppositipetalæ corolla medium superantes sed petalorum apicem non attigentes. Carpella 5, pauciovulata, glabra, in stylos carpellis breviores attenuata, placentis a gracili ligamine constitutis. Squamæ 5, sublineares, basi leviter dilatatæ, medio coartatæ, apice leviter dilatatæ, inflatæ et obtusæ, longiores quam latiores. Folliculi 5, pauciseminati, divergentes, lateribus internis non gibbosis; semina testa duabus extremitatibus nucleum non superante.

Planta 3-5 cm. longa. Caules steriles $6 \mathrm{~mm}$. longi. · Folia $4.50-7$ $\mathrm{mm}$. longa, $2-3 \mathrm{~mm}$. lata. Inflorescentia $9 \mathrm{~mm}$. longa, I $2 \mathrm{~mm}$. lata. Pedicelli $0.60 \mathrm{~mm}$. longi. Calycis pars concreta $\mathrm{I}-\mathrm{I} .20 \mathrm{~mm}$. longa, pars libera $4.5^{-}-5.5^{\circ} \mathrm{mm}$. longa, I.75-2 $\mathrm{mm}$. lata. Corolla pars concreta 0.I $5-0.25 \mathrm{~mm}$. longa, pars libera $5.50-6 \mathrm{~mm}$. longa, $0.55 \mathrm{~mm}$. lata. Staminum oppositipetalorum filamentorum pars concreta $1.60-2 \mathrm{~mm}$. longa, pars libera $3.50 \mathrm{~mm}$. longa. Styli $2 \mathrm{~mm}$. longi. Squamæ I.40 $\mathrm{mm}$. longæ, $0.50 \mathrm{~mm}$. latæ.

Guatemala, on rocks of the Sierra Madre, $400 \mathrm{~m}$; flowers yellow, June זо, I882. [F. C. Lehmann, No. I528. Type in herb. Barbey, Boissier]. 






UNIVERSITY OF ILLINOIS-URBANA

580.5FB

COO1

FIELDIANA, BOTANYSCHICAGO

2 1900-16

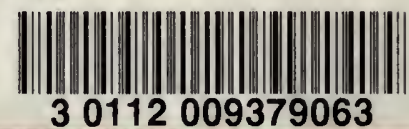

